Slobodan Cvetanović ${ }^{1}$

University of Niš

Faculty of Economics

Danijela Despotović ${ }^{2}$

University of Kragujevac

Faculty of Economics

Vladimir Nedić ${ }^{3}$

Technical College of Applied Studies

Kragujevac
ORIGINAL SCIENTIFIC ARTICLE doi:10.5937/ekonomika1901001C

Received December, 17, 2018

Accepted: February, 15, 2019

\title{
RISKS OF ENERGY SECURITY
}

\begin{abstract}
According to its significance, energy production is in the same group of activities like production of food and raw materials, and supply of necessary drinking water. The lagging in those forms of production has negative impact on economic growth and development of countries and regions as a whole. Therefore, the problems of development of energy sector cannot be observed as isolated from the development of overall social-economic development of a country, even out of context of development of international political and economic relations. In that light,energy security is one of the most pronounced risks in the modern world. Unlike the previous period when oil was predominantly considered the factor of energy security, nowadays, the discussion about the energy security takes into account energy sources as a whole. Due to the continuously growing demand for energy (resulting from increased economic activities and raising living standard), on the one hand, and the growing number of uncertainties of different origin that accompany production, transport, distribution, storage, and final energy consumption (environmental, technical, economic, political, security), on the other, energy security has become one of the most important global development goals.
\end{abstract}

Key words: energy security, environmental risks, economic risks, political risks, technological risks.

JEL classification: $Q 40, Q 50$

\section{РИЗИЦИ ЕНЕРГЕТСКЕ СИГУРНОСТИ}

\section{Апстракт}

Према важности, производюа енергије налази се у истој групи делатности као и производюа хране и сировина, као и обезбеђење потребних количина воде за пиће. Заостајање у тим облицима производње негативно делује на

\footnotetext{
${ }^{1}$ slobodan.cvetanovic@eknfak.ni.ac.rs

2 ddespotovic@kg.ac.rs

${ }^{3}$ vnedic@kg.ac.rs
} 
економски раст и развој земаља и региона у целини. Зато се проблеми развоја енергетског сектора не могу се посматрати изоловано од развоја укупног друштвено-економског развоја неке земље, па чак ни ван контекста развоја међународних политичких и економских односа. У том светлу, енергетска сигурност представља један од израженијих проблема данашњег света. 3 а разлику од ранијег периода када је акиенат у разматрању категорије енергетске сигурности био на нафти, у овом веку, расправљајући о феномену енергетске сигурности, имају се у виду енергетски извори третирани као иелина. Услед континуирано растућих потреба за енергијом (условљених увећањем привредних активности и подизањем животног стандарда људи), с једне, и све бројнијих неизвесности различитог порекла које прате производњу, пренос, односно транспорт, дистрибуичиу, складиштење и финалну потрињу енергије (еколошких, техничких, економских, политичких, безбедоносних), с друге стране, реализација енергетске сигурности је промовисана у један од најзначајнијих ичиљева глобалног развоја.

Кључне речи: енергетска сигурност, еколошки ризик, економски ризии, политички ризици, технолошки ризици.

\section{Introduction}

Adequate explanation of the problem of energy security and ability to offer appropriate solutions need to be understood first (Yergin, 2006; Kruyt, et al., 2009). The question refers to the essence of phenomenon, increasingly circulating in theoretical debates and public discussions among representatives of various political options. Hence the issue should be carefully analysed. Energy security should not be identified as energy efficiency (Winzer, 2012). On the other hand the difference between energy and thermodynamic efficiency should be borne in mind. The importance of external dimension of energy policy with the predominant problem of energy security is often emphasized by many authors, while environmental policy heavily influences the internal dimension of energy policy (Kern \& Smith, 2008). The emergence of various risks follows the implementation of energy policies in individual countries and hence regional economic integration (Yépez-García \& Dana, 2012). Thus, not only that all these facts should be known, but also the instruments of their measuring and minimising (Löschel, Moslene \& Rübbelke, 2010; Kruyt, et al., 2009). To do so, the role of state, market, technology and the interests of various stakeholders must be included. Therefore, the risk management is essentially important in ensuring conditions for upgraded energy security (Ang, Choong \& Ng, 2015).

The subject of the paper is identification of risks related to energy security, which is one of the most significant issues of global development. The aim is to explain the nature of uncertainties that unavoidably accompany the production, transmission, distribution, storage and final support of energy in contemporary living and manufacturing conditions. The starting point is that energetic uncertainty, which would be followed by favourable energy prices and realisation of climatic aims can be achieved only by sustainable development of energy based on high energy efficiency, renewable energy and creation of 
"clever" energy infrastructure. In order to provide conditions for improvement of energy security, it is necessary to manage risks that may be ecological, economic, political and technological.

\section{Energy as a factor of economic growth and risks of energetic security}

During a long period of development of economic theory, energy as a factor of economic growth has not received the attention it has in practice. Energy is tested as intermediary goods while according to other, still recognised models of neoclassical economy, economic growth is ascribed to technological progress and the knowledge based on that progress. Economic theory that considered the quantity of available energy in the observed economy was endogenously determined, logically under the influence of biophysical and economic limitations. However, the fact is that the process of manufacturing involves the transformation of matter from one form into another, which includes the use of energy. (Jakovec, 2015).

By placing the energy into the centre of economic activities its undisturbed utilisation is recognised as a significant precondition of economic growth. It means that economy should be observed as an energetic system which includes energetic courses and conversions that culminate exactly in manufacturing of goods and services (Imran i Siddiqui, 2010, p. 206).

According to ecological economics, energy is the most significant primary manufacturing factor. This is justified by the fact that thanks to the energy, human society progressed from rural to post-industrial during two human lifetimes, or to put it metaphorically, from mattock to a computer, or from manual to machine work. To manufacture, transport, accumulate and innovate energy is the imperative of economic growth (Višković, 2008, p. 25). Hence, stable energy supply is the base of total economic activity (Abaidoo, 2011).

According to its significance, the production of energy is ranked the same as the production of food and raw materials together with water supply (Rasul \& Sharma, 2016). The stagnation of energy production limits the economic growth and development in certain countries. Therefore, the problems of production of energy can neither be considered nor investigated without the development of total social and economic system of a country, even out of the context of development of political and economic relationships (Dekanić, 2011). Bearing this in mind, it can be concluded that growing risks of energetic security are a significant, limitation factor of economic growth at global level.

The need for energy increases with the economic development. Hence the stability of sufficient energy supply acquired growing global importance. The problem here is not only how to provide sufficient amount of energy, but also how to create balance in satisfaction of energy needs and establishment of social and ecological acceptability.

Energetic security is one of pronouncedly significant problems today. It is not static but utterly dynamic category, dependant on numerous risks, such as market oscillations, international policies, and the behaviour of economically developed countries (Fig. 1). Unlike the previous period when the focus of analysis of energetic security was 
on oil, in this century, discussions on the phenomenon of security of energetic sources as a whole should be borne in mind. Due to continuously growing needs for energy (conditioned by the increase of economic activities and elevation of life standard of the population) on the one hand, and increasingly numerous uncertainties of various origin that accompany production, i.e. transmission, i.e. transportation, distribution, storage and final consumption of energy (ecological, technical, economic, political and security) on the other, the realisation of energetic security is promoted to one of the most significant aims of global development.

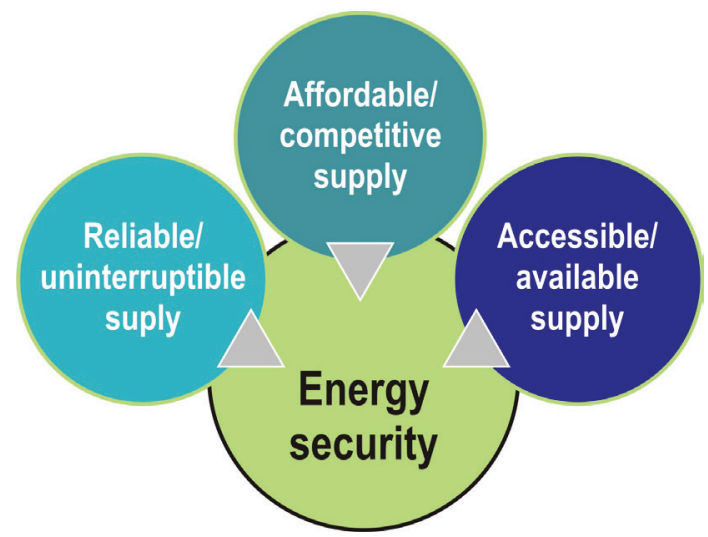

Figure 1: Defining energy security (World Energy Council. n.d.)

There are numerous risks of safe energy supply. Depending on the set criteria, they can be classified in different ways. This paper takes in account the quarterly distinctions between environmental risks, economic risks and technological risks. Each of them will be theoretically explained in short.

\section{Environmental risks}

At the end of the twentieth and in the twenty first centuries the location of most important sources of energy production has been basically important for economic and security policies in the countries worldwide. The increasing use of fossil fuels in the production of energy has especially contributed to the manifestation of the phenomena of strong environmental changes, most visibly manifested as global climate change. During the last thirty years many countries paid serious attention to incorporation of energy security requirements into the policy of energy and sustainable development (Martínez, 2015; Filipović \& Despotovic, 2014). Now the changes of energy policy concept are being made. They include energy security, increasing significance of renewable energy sources, improvement of energy efficiency and environmental protection as the most significant (Fig. 2). 


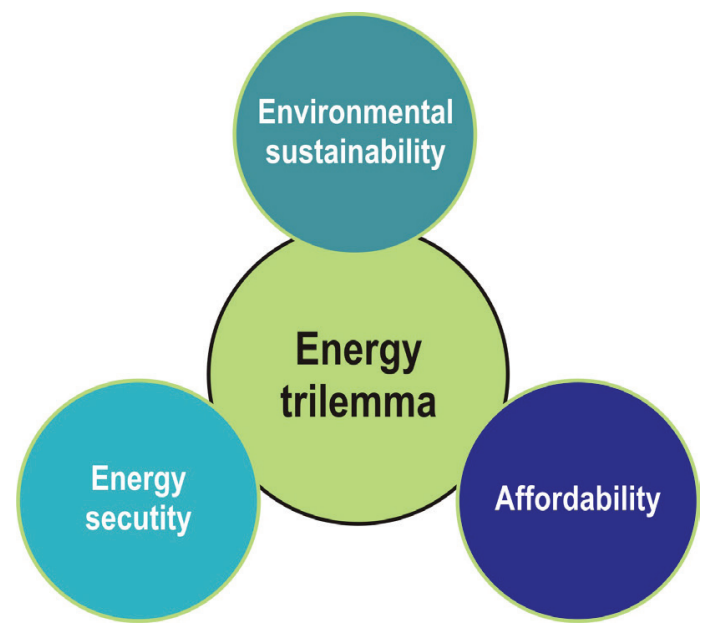

Figure 2. The energy trilemma (Gove, Beresford \& Williams. 2016).

This century is characterised by the risk related to the climate change as an important challenge. Speaking of the risks associated with the energy security, a high level of environmental protection must be guaranteed (Heffron, McCauley \& Sovacool, 2015). In addition to environmental, the climatic and health risks should also be borne in mind together with the impact of unconventional fossil fuel extraction (Fig. 2). This includes risks of accidents at nuclear power stations and plants as long as they are in operation.

Another risk is related to nuclear plants and their radioactive waste and disposal facilities that can experience terrorist attacks. In addition, the process of ' $g$ lobal warming' due to greenhouse effect may result in climate change. The greenhouse effect means that the gases such as carbon dioxide, methane, nitrous oxide, and water vapour retain infrared radiation like the glass in a greenhouse, thus preventing the infrared radiation to release into the Earth's atmosphere. This higher level of greenhouse gases undoubtedly results in increase of temperature on Earth. Gas emissions increase the global temperature, especially compared to natural fluctuations of temperature levels.

The utilisation of land including the land for urban purposes is found to be responsible for nearly half of the changes in temperature differences in specific regions. Besides, although construction materials such as concrete, used for roads and buildings and other structures tend to absorb sun heat, they do not reflect it. Increasing deforestation eliminates natural cooling obtained by shadows. Al those factors increase regional warming, known in literature as the urban "heat island effect" (Debbage \& Shepherd, 2015). It should be emphasized that this effect differs from global warming, but their influence may affect global climatic changes. Therefore, in the conditions of global climatic changes, energy security management requires making decisions under uncertain conditions. In addition, the link between the production of energy and human health should not be ignored, especially related to risks of environmental pollution caused by thermal power plants. 


\section{Economic risks}

Economic risks are related to vulnerability of economy price "shocks", which negatively influence economic growth. In that respect, cost-effectiveness of nuclear choice not only provides autonomous and cheaper production, but also allows for the creation of predictable energy price, which is contrary to oil and gas prices (Nakata, 2004).

After a series of events that led to serious price fluctuations and difficulties in transportation of gas across certain territories, the energy security has become a key issue of energy policies in most EU countries that import energy. In comparison to the previous period, energy market is more turbulent. These new circumstances resulted in the need for saving and creation of strategic primary energy reserves. Hence economic risks related to energy projects can be classified as those related to market (with consumer prices below the cost of production and maintained by subsidies, or a decline in fuel or technology demand), macroeconomic environment (that includes unstable or inflationary economic environment and fluctuations in foreign exchange rates) and finance (i.e. interest rate rise). In time, investors and financers have become skilled in reacting to risks, thus avoiding them. One of possible solutions for risk reduction is to make fixed or guaranteed-price contracts. Market risks can also be diminished by making long-term energy supply contracts, since the key economic risk related to energy security is possible fluctuation in the energy price. Like in all other domains, the price is formed on the basis of supply and demand. When energy security is considered, shortterm effects of prices can be analysed by the factors of reduced demand, while long-term effects by those that cause the energy supply growth.

The short-term measures taken in order to drastically reduce the demand for energy is not an effective strategy. It is important to make integrated planning of energy demand and energy supply at this level, and give priority to reduced demands and decentralized solutions, thus achieving cost-effective security in supply, and avoiding unnecessary or excessive energy infrastructural investment. A significant contribution to energy security can be made by investment in reduced energy demands, particularly in buildings and industry, which can stimulate economic growth and create new jobs. To reduce energy demand, especially for heating and use savings and energy efficiency is of vital importance for a few reasons such as positive effect on energy security, availability of energy and economic growth, competitiveness, fight against energy poverty and creation of sustainable jobs. International Energy Agency suggests that investment in energy efficiency and development of energy sector are the best return of investment from any source, and hence energy efficiency should be considered significant source of energy. Energy efficiency and demand side responce should equally compete with the production capacity, bearing in mind urgent and remarkable problems of energy security. All these should be taken into account in industrial policy, especially energy efficiency and renewable energy sources, thus contributing to re-industrialisation and achieving the share of industry in gross domestic product. Potential energy savings are meant for all sectors of economy, including industry, trade, construction, agriculture and service sectors. 


\section{Political risks}

Energy security is increasingly important political issue, which cannot be fully responded by market mechanisms. Unlike intrusive state interventions, typical of the past, each form of public intervention should be conducted through the partnership between the state and private enterprises. According to Multilateral Investment Guarantee Agency of the World Bank (MIGA), political risk is defined as the probability of disruption of company operations by using political forces and events, regardless to whether they occur in host countries or are a result of changes in the international environment. Political risks are related to state (e.g. quality of legal system and political institutions, possible expropriation and nationalization, trans-boundary problems, etc.), policies and regulations (sustainability and validity of energy policy framework, changes in environmental policy and standards, stability and consistency of tax system), and complexity of business environment (e.g. permits and licenses) (Stojanovic \& Đordjevic, 2016). While previously, risks were mostly related to oil supply (since the fuel was imported from politically unstable countries), today, liquid gas supply is a prominent risk factor (as it is the fuel to which Western systems are currently turning). In fact, gas supply is controlled by relatively small number of countries led by Russian Federation and Iran, with over $40 \%$ of world supply. The favoured option was a misconception: it seemed that gas differed from oil in the aspect of security. But this changed after the gas crisis in Ukraine in 2008. Development of geopolitical crises of regimes in a number of African countries such as Libya and Syria, then the war in Middle East led to changes in the previously adopted energy strategies of most European countries, which were able to provide long-term supply stability exclusively in case of ensured energy security, and thus develop conditions for production of goods and services that could provide satisfactory macroeconomic performance over a long period. Therefore, oil and gas companies are constantly exposed to risks in both internal and external environment. In addition, nationalization is also a source of political risk, which often occurred in the course of history. Today, expropriation is seen as a risk of taking control over companies by the government for a fee, which is typical of less developed countries. Among other political risks, the currency convertibility, breach of contracts and violation of financial organisations should also be mentioned. Political risks of the investors are especially pronounced in the countries where legislation and sanctions for violation of rules are not properly developed, hence the investors face problems in the realisation of their oil and gas supply projects, which is mainly the characteristic of poor and underdeveloped countries. And finally, there is a constant risk for investors in the domain of energy, where the projects may be jeopardized due to instability or political changes in the host country.

\section{Technological risks}

Technological risks include technical reliability of energy supply on separate markets. Nowadays, the most serious and expensive disruptions take place within the end markets, not outside them, which is paradoxical and significantly concerns the Western world. Many countries experience emergencies related to gas production and problems of transmission network. If these events are considered an alibi, their role is to hide the real causes which include either lack of investment or economic integration 
of markets, thus resulting in their mutual dependence and individual vulnerability. If infrastructure is not adequately reinforced, the network systems are extremely sensitive to any unpredictable occasion. The increasing complexity of energy networks is more and more exposed to security risks, mainly related to their IT infrastructure. The risks also include the so-called cyber weapons that can attack infrastructure in increasingly sophisticated ways and are more accessible to a wider circle of people. Thus, one of the most urgent tasks is to find an effective response to cyber security risks, using the sources that would ensure energy security.

\section{Conclusion}

Energy security has its geopolitical dimension. Namely, the issue of energy supply where some developed countries are still importers, leads a great number of developed counties to energy dependence. Energy security is an important topic in shaping and planning energy policy and strategic development.

In the conditions of intensive environmental changes, it is increasingly evident that energy based on the use of fossil fuels significantly contributes to visible manifestation of these negative phenomena on a global scale.

Economic risks occur due to economic vulnerability to "shocks" induced by prices, which has a negative impact on economic growth. The cost-effectiveness of nuclear choice was not obvious in guaranteeing autonomy or cheaper production only, (although those that adopted it benefit now), but, above all, in the fact that this option allowed for the creation of a predictable energy cost/price, contrary to recent experiences with oil and gas.

Political risks are associated with state (quality of political institutions and the legal system; possibility of expropriation or nationalization; transboundary issues and problems), policies and regulations (credibility and sustainability of the energy policy framework; changes in standards or other regulations in environmental policy; consistency and stability of the tax system) and complexity of the business environment (permits, licenses).

Technological risks are related to technical reliability of energy supply within individual markets. It should be emphasized that the most serious and most expensive "disruptions" nowadays result from the events within, not outside end markets, which is a special concern of Western world.

\section{References}

Abaidoo, R. (2011.). "Economic growth and energy consumption in an emerging economy: augmented Granger causality approach", Research in Business and Economics Journal, Volume 4, August 2011, http://www.aabri. com/ manuscripts/11843.pdf

Ang, B. W., Choong, W. L., \& Ng, T. S. (2015). Energy security: Definitions, dimensions and indexes. Renewable and sustainable energy reviews, 42, 1077 1093. 
Debbage, N., \& Shepherd, J. M. (2015). The urban heat island effect and city contiguity. Computers, Environment and Urban Systems, 54, 181-194.

Dekanić, I. (2011.). Geopolitika energije-uloga energije u suvremenom globaliziranom društvu. Golden marketing-Tehnička knjiga, Zagreb.

Filipović, M., \& Despotovic, D. (2014). Analysis of sustainable competitiveness of european countries in 2013. Ekonomika, 60(4).

Gove, B., Beresford, A., Williams, L. (2016). The RSPB's 2050 energy vision: Meeting the UK's climate targets in harmony with nature. Technical Report, Researchgate.

Heffron, R. J., McCauley, D., \& Sovacool, B. K. (2015). Resolving society's energy trilemma through the Energy Justice Metric. Energy Policy, 87, 168-176.

Imran, K., Siddiqui, M.M. (2010). "Energy Consumption and Economic Growth: A Case Study of Three SAARC Countries", European Journal of Social Sciences, 16 (2): 206-213.

Kern, F., \& Smith, A. (2008). Restructuring energy systems for sustainability? Energy transition policy in the Netherlands. Energy policy, 36(11), 4093-4103.

Kruyt, B., van Vuuren, D. P., de Vries, H. J., \& Groenenberg, H. (2009). Indicators for energy security. Energy policy, 37(6), 2166-2181.

Löschel, A., Moslener, U., \& Rübbelke, D. T. (2010). Indicators of energy security in industrialised countries. Energy Policy, 38(4), 1665-1671.

Martínez, C. I. P. (2015). Energy and sustainable development in cities: A case study of Bogotá. Energy, 92, 612-621.

Nakata, T. (2004). Energy-economic models and the environment. Progress in energy and combustion science, 30(4), 417-475.

P. Jakovac, N. Vlahinić Lenz. (2015). Uloga energije s aspekta ekonomske teorije Ekonomski Pregled, 66 (6) 527-557

Rasul, G., \& Sharma, B. (2016). The nexus approach to water-energy-food security: an option for adaptation to climate change. Climate Policy, 16(6), 682-702.

Stojanovic, M., \& Đordjevic, M. (2016). The role of environmental taxes in Serbian tax system. Ekonomika, 62(4), 75.

Višković, A. (2008). Svjetlo ili mrak: o energetici bez emocija. Akademija tehničkih znanosti Hrvatske, Lider press, Zagreb.

Winzer, C. (2012). Conceptualizing energy security. Energy policy, 46, 36-48.

World Energy Council. (n.d.). Retrieved November 20, 2018, from https://www. worldenergy.org/publications/2018/trilemma-report-2018/

Yépez-García, R. A., \& Dana, J. (2012). Regional Energy Integration. World Bank Group.

Yergin, D. (2006). Ensuring energy security. Foreign affairs, 69-82. 